\title{
"The Grace of God" as evidence for a written Uthmanic archetype: the importance of shared orthographic idiosyncrasies ${ }^{1}$
}

\author{
Marijn van Putten \\ Leiden University \\ m.van.putten@hum.leidenuniv.nl
}

\begin{abstract}
This paper takes a novel approach to the question of when and how the text of the Quran was codified into its present form, usually referred to as the Uthmanic text type. In the Quran the phrase ni mat allāh/rabbi-ka "the grace of god/your lord" can spell ni mat "grace" either with $t \vec{a}$ " or $t \vec{a}$ marbütah. By examining 14 early Quranic manuscripts, it is shown that this phrase is consistently spelled using only one of the two spellings in the same position in all of these different manuscripts. It is argued that such consistency can only be explained by assuming that all these manuscripts come from a single written archetype, meaning there must have been a codification project sometime in the first century. The results also imply that these manuscripts, and by extension, Quran manuscripts in general, were copied from written exemplars since the earliest days.

Keywords: Quranic studies, Early Quran manuscripts, Early history of the Quran, Orthographic idiosyncrasies, Quranic archetype
\end{abstract}

\section{Introduction}

Throughout the history of Quranic studies, a general unease about the date of the codification of the textus receptus ne varietur can be perceived. Traditionally, it is believed that it was the third caliph 'Uthmān b. 'Affān who codified the rasm, or consonantal skeleton, of the text as we have it today. This was famously challenged by Wansbrough (1977), who posited that the collection of the canonical text can only have taken place as late as two or three centuries after the date traditionally assigned to it.

With the discovery and description of many early Quranic manuscripts that are clearly earlier than the late date proposed by Wansbrough, it is now clear that this position in its most extreme form is to be discarded. Nevertheless, many of the reasons for scepticism about an early date for the compilation of the text have not been dispelled, and a general unease remains in the field of Quranic studies.

This paper aims to show not only that all the early Quran manuscripts descend from a single written archetype, but also that the text was clearly spread

1 I would like to thank Mehdy Shaddel, Sean Anthony, Ilkka Lindstedt, Fokelien Kootstra, Lameen Souag, and Ghilène Hazem for giving valuable input on an earlier version of this paper. 
through the copying of a written exemplar, and not by copying through dictation or transcriptions of an oral tradition. Considering the early date of some of the many Quranic manuscripts discussed here (many of which must date from the early Umayyad period), it seems highly unlikely that this written archetype was standardized much later than the time of 'Uthmān's reign, and therefore the data can be seen to corroborate very precisely the traditional Muslim account.

\section{The Uthmanic text type}

The pioneering work on the Sanaa palimpsest by Sadeghi and Bergmann (2010), and later Sadeghi and Goudarzi (2012), has significantly contributed to a better understanding of the textual history of the Quran. Their use of stemmatics to look at the lower text of the Sanaa palimpsest allowed them to demonstrate that its text must descend from a different text type from that which is generally considered to be the Uthmanic text type ${ }^{2}$ and, moreover, to assert that some of the Quranic text attributed to "companion muṣafs"3 can be considered to constitute alternative text types. The Sanaa palimpsest, with its many striking variants (which often agree with the non-Uthmanic companion muṣhafs), should likewise be thought of as a separate text type.

Sadeghi defines the Uthmanic text type as agreeing with the text of the 1924 Cairo Edition of the Quran, a tradition that "reportedly began with the codices 'Uthmān disseminated as the ancestors of all the manuscripts in the textual tradition". These codices all agree on: 1 . the order of the surahs; 2 . the order of the verses within each surah; and 3. the content of these verses in terms of individual words (Sadeghi and Bergmann 2010: 347).

The vast majority of known Quranic manuscripts (all but the Sanaa palimpsest, in fact) are of the Uthmanic text type, and only minor variations are present in this text type. Larger disagreements on how to read the consonantal skeleton of the Quran have developed in the reading traditions, but these have little consequence in the overall clear and consistent unity of the Uthmanic text type. The question of how ancient this uniform text type is, however, has led to

2 This view has recently been challenged by Hilali (2017), who claims that none of the variants that Sadeghi and Goudarzi (2012) attribute to non-standard readings attributed to companions of the Prophet can in fact be found in the lower stratum of the text. As Hilali's new edition of the Sanaa palimpsest regrettably does not reproduce the photos to which she had access, we have only her word against that of Sadeghi and Goudarzi wherever she claims not to see traces of a variant that they identified. Despite this, at least one of the variants attributed to Ibn Muhayṣin, namely mikayl مكيل in Q 2: 98, instead of the ميكيل of the Cairo edition, is also present according to Hilali. Sadeghi and Goudarzi (2012: 116) reconstruct a final $\downarrow$ that apparently cannot be seen in the palimpsest, whereas Hilali (2017: 144 f.) takes a more conservative approach and simply reads مكي However, claiming that it therefore gives no evidence for this variant (as she equally admits to the missing first $ى$ ) is an unwarranted level of radical doubt. As Sadeghi and Goudarzi say: "Ibn Muhayșin's reading is the only one compatible with the rasm".

3 Such as that of Ibn Mas 'ũd, which is usually held to have stayed in use in Kufa as an authoritative exemplar for recitation, even after the Uthmanic codex was taken to be the "official text" in the rest of the Muslim world (Nasser 2013: $55 \mathrm{f}$.). 
contentious discussions among academics in recent decades, and a general unease as to when exactly the text was completed permeates much of the writing on this subject.

Donner (2008: 31 ) suggested that one of the five most consequential questions currently presented to Quran scholars is whether or not there was an early textual archetype for the present Quran. Wansbrough (1977) famously argued that the Quran was not compiled until two or three hundred years after the Prophet's death, whereas Burton (1977) argued that it had been compiled by the Prophet himself rather than by 'Uthmān. Since then many authors have weighed in on these questions, but no clear consensus has emerged. Sinai (2014a: 276) speaks of an "emergent canon model", which prefers a closure of the received Quranic text at around $700 \mathrm{CE}$, rather than the traditional date of around $650 \mathrm{CE}$. He presents several counter-arguments that have been proposed, but in his defence of the traditional date, in the second part of the article (Sinai 2014b: especially $520 \mathrm{f}$.) he admits that it is difficult to tell whether some parts were not corrected or added until around $700 \mathrm{CE}$.

Neuwirth expresses a similar uncertainty, and suggests that the traditional scenario of the Uthmanic redaction is "... plausible though not possible to prove" (Neuwirth 2003: 11).

Motzki (2001) set out to prove the traditional narrative by tracing back the accounts of this collection through the isnad-cum-matn method, and expresses pessimism about the usefulness of manuscripts in helping to date the codification of the Quran, asserting that "the fragmentary character of most of the oldest Qur'ānic manuscripts does not allow us to conclude with certainty that the earliest Qur'āns must have had the exact same form, size and content as the later ones. Thus manuscripts do not seem to be helpful (as yet) concerning our issue" (Motzki 2001: 2).

In recent years authors have advanced several strong arguments that speak in favour of an early redaction of the Uthmanic text type. The traditional literature on the rasm of the Uthmanic codex is right about many minute details. According to Sadeghi, it is highly unlikely that it is wrong about its main underlying assumption: the compilation of the Quran by 'Uthmān (Sadeghi and Bergmann 2010: $366 \mathrm{f}$.). This argument relies largely on the path-breaking article by Cook (2004), which shows that the variants in the rasm reported for the different regional codices of Kufa, Basra, Damascus and Medina by al-Dānī in his al-Muqni' fì Rasm Mașāḥif al-'Amṣār form a stemma. Cook shows, for example, that the Damascene muṣaf has several unique readings, and shares several others with the Medinan Mushaf, but never shares variants with the Kufan or Basran. These patterns clearly indicate that the transmission and introduction of these variants point to only about seven different possible stemmata, and that they agree with the account of the transmission of the text. As medieval Muslim scholars had no concept of stemmatics, the very fact that such a pattern arises leads Cook to conclude that "we have to do with genuine transmission from an archetype" (2004: 104).

Since they are not based on actual manuscripts and Cook does not compare them to the manuscrpts, the reports al-Dānī produced could be about any group of interdependent manuscripts copied from each other, and may not necessarily have had anything to do with the actual mașāhif al-'amṣār, if these existed at all. 
However, that the archetype posited by Cook must have been very early is certainly clear from Dutton's work on the Codex Parisino-Petropolitanus and Or. 2165, both early Hijazi Quranic manuscripts which show all the variants of the Syrian muṣhaf, but none attributed to the other muṣhafs, as reported by al-Dāni (Dutton 2001; 2004). Al-Dānī's report must, therefore, be based on a reality that can be confirmed in the manuscript tradition.

Cook's arguments, combined with their confirmation in the manuscript evidence, make a strong case for an extremely early codification and distribution of the Uthmanic text type. It is then consistent with the traditional account of the codification and distribution of the four regional codices. While I find Cook's arguments convincing, they seem to have gone to a large extent unnoticed, or have not been found to be fully convincing. I would therefore like to offer yet another argument that points to a written archetype of the Uthmanic text type which, moreover, shows that this text type was consistently copied from a written exemplar and not transmitted, as may be imagined, through dictation or oral transmission.

\section{Orthographic idiosyncrasies}

As noted in the previous section, in terms of surah order, verse order and even the specific wording, all Quranic manuscripts, with one exception, belong to the same Uthmanic text type. What remains unclear, however, is how this text type was transmitted and when it was established in its fixed form. A definitive answer to this question cannot be found by examining the Muslim tradition, but should rather be based on a study of the text of the early Quranic manuscripts. Careful examination of these manuscripts shows that even the specific rasm with all its orthographic idiosyncrasies points to a single written archetype, which was copied from one muṣhaf to the other through copying from a written exemplar.

Even a cursory examination of the Cairo edition of the Quran reveals many spellings which do not conform to Classical Arabic orthography. These spellings in the Cairo edition could simply be reproducing fossilized orthographic idiosyncrasies that originate in pre-classical orthographic practices. But some such non-standard, pre-classical spellings are in seemingly free variation. These include pairs such as rahmat allāah (spelled both as رحمد الله allath)

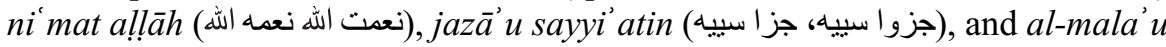
(الملوا، الملا). Such orthographic idiosyncrasies occur rather frequently in the Quran. When we find such variations in spelling, we must conclude that they carry no linguistic value, as they express the exact same phrase with the same meaning. Such spelling variations then appear to have been attributable to the discretion of the scribe.

But there is much more to these orthographic idiosyncrasies than merely reflecting the whims of a scribe. Such orthographic idiosyncrasies allow us to show that the Quranic manuscripts go back to a single written archetype from which all of these documents were copied. If two manuscripts do not descend from copies of a single archetype, we would not expect the same spelling to occur in the exact same location time and time again. However, this is exactly what we find: highly idiosyncratic spellings occur again and again in the 
same spelling in the exact same location across all early Quranic manuscripts. Such variation can only be the result of precise written transmission.

\section{An example: Ni mat Allāh}

A good place to show that the orthographic idiosyncrasies point to a single written archetype is through the feminine nouns in the construct state. While in Quranic orthography, feminine nouns in construct are usually written with a final $\llcorner$, as is the case in Classical Arabic orthography, a rather large proportion (about 22 per cent) of the feminine constructs are written with $ت$ instead. For some common phrases, the distribution between these two forms is almost equal, and for some lexical items $\underset{\sim}{\boldsymbol{H}}$ is the only attested spelling. The items where the two forms are equally predominant are a particularly good place to show that orthographic idiosyncrasies are consistently reproduced. Table 1 gives an overview of the feminine nouns in construct that have alternation

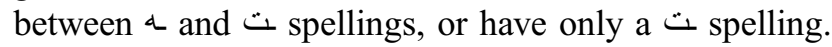

I will focus here on the lexical item that is most common and, moreover, has an almost completely equal distribution of the two spellings, namely ni mah "grace". This word occurs in construct either with allāh or rabbi-ka/-kum/-i "your/my lord". The noun with which ni mah is in construct is irrelevant for the choice of the two spellings, and it occurs spelled in both ways in front of either noun in the Cairo edition.

\section{The manuscripts}

The spelling of ni mah in construct in its 23 occurrences in the Quran has been examined across 14 Quranic manuscripts. In Table 1, abbreviations for these manuscripts have been used. The following overview gives some information about these manuscripts; this information has been taken from the Corpus Coranicum website (www.corpuscoranicum.de) unless specifically indicated otherwise.

Table 1. Feminine construct phrases with $\bullet$ in the Quran

\begin{tabular}{|c|c|c|}
\hline & $\alpha$ & $ت$ \\
\hline نعمه & 12 & 11 \\
\hline رحمه & 6 & 7 \\
\hline لعنه & 5 & 2 \\
\hline سنه & 8 & 5 \\
\hline كلمه & 8 & 5 \\
\hline جنه & 4 & 1 \\
\hline شجره & 2 & 1 \\
\hline قره & 2 & 1 \\
\hline امر(ا)ت & 0 & 7 \\
\hline غيبت الجب & 0 & 2 \\
\hline معصيت الرسول & 0 & 2 \\
\hline بقيت الله & 0 & 1 \\
\hline فطرت الله & 0 & 1 \\
\hline ابنت عمرن & 0 & 1 \\
\hline
\end{tabular}


SU = Codex Șan 'ā' I, upper text = Sanaa, Dār al-Makhṭūtāt, DAM 01-27.01 + Hamdūn 2004 + auctioned folios Christie's 2008; Bonhams 2000; Sotheby's 1992 and Sotheby's 1993

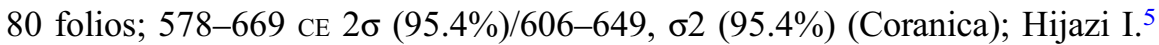

The upper text of the Sanaa palimpsest must of course post-date the lower text, but can still be considered an early Quranic manuscript from the first or early second century on the basis of its orthography.

BL $=$ British Library, Or. $2165+$ BnF Arabe 328e + Dār al-' Āthār al-'Islāmiyyah, Kuwait 1 LNS 19 CA $^{\text {ab }}$ (bifolio),

128 folios; second half of the first century (Dutton 2004: 66); Hijazi II (Déroche 1983: 62, $\mathrm{n}^{\mathrm{o}} 7$ ).

A3 = Arabe $331+$ Ms. Leiden Or. 14.545b + Ms. Leiden Or. 14.545c

58 folios; first century, ${ }^{14} \mathrm{C}$ : 652-763, o2 (95.4\%); Kufi B Ia (Déroche 1983: 67, $\left.n^{\circ} 14\right)$.

\section{CA1 $=$ Codex Amrensis 1}

75 folios; $c$. first half second/eighth century(?) (Cellard 2017: 15); late Hijazi (Cellard 2017: 7)/Hijazi I (Déroche 1983: 59, $\mathrm{n}^{\circ}$ 1).

Edited and published by Cellard (2017).

$Q=$ Ms. Qāf 47+ Ms. Or. Fol. 4313

36 folios; first century, ${ }^{14} \mathrm{C}$ : 606-652, $\sigma 2$ (95.4\%); Hijazi.

\section{S = Berlin, Staatsbibliothek: Samarkand Kodex (Faksimiledruck)}

353 folios; dated to about 700-850. Kufi D I. ${ }^{6}$

I have based my readings on the facsimile reproduction available on the Corpus Coranicum website.

W= Berlin, Staatsbibliothek: Wetzstein II 1913 (Ahlwardt 305) + BnF Arabe 6087

210 folios $+6 \mathrm{ff}$; Second half first century/early second century, ${ }^{14} \mathrm{C}$ : $662-765$, б2 (95.4\%); Kufi B Ia (Déroche 1983: 67, nº 160).

4 For details on the folios of the Sanaa Quran auctioned off at Christie's, Bonhams and Sotheby's, see Sadeghi and Bergmann (2010: 354).

5 For a discussion on the classification of the early Quranic styles see Déroche (1983; 1992). This document is classified as Hijazi IV or Kufi B in Corpus Coranicum. However, Hijazi I seems more apt. One of the main factors Déroche uses to distinguish the styles is the shape of the $h \vec{a}$. This document has a very distinctive heart-shaped $h \vec{a}^{\prime}$ which it shares neither with Hijazi IV nor with Kufi B. The only style I am aware of with a similar shape of the $h \vec{a}$ is the Hijazi style of Hand E of the Codex Parisino-Petropolitanus (Déroche 2009: 41, 193 f.).

6 Kufi C I is the category reported on Corpus Coranicum but, Kufi D I is clearly much more in line with what we find, as for example is visible in the curved, rather than straight $\check{g} \bar{\imath} m / h \vec{a} / h \vec{a}^{\prime}$ and the strict $u$-shape of the final $q \bar{a} f$. 
The text contains insertions and corrections by later hands, but none of them are corrections of the feminine ending. The six folios of Arabe 6087 have been identified by Corpus Coranicum as belonging to this manuscript.

Zid = Gotthelf-Bergsträßer-Archiv: Meknes, Privatbibliothek des Scherifen 'Abdarraḥmān b. Zīdān: kufischer Korankodex

380 folios; c. eighth/ninth century; Kufi B II. ${ }^{7}$

Rather damaged, and frequently difficult to read due to the low quality of the pictures.

K = Kairo, al-Maktaba al-Markaziyya li-l-Makhṭūțāt al-'Islāmiyya: Großer Korankodex

1087 folios; not before 700; Kufi B I b or B II.

\section{$\mathbf{C P}=$ Codex Parisino-Petropolitanus}

98 folios; $c$. third quarter of the first/seventh century (Déroche 2009: 177); a fairly large Quranic manuscript, edited and published by Déroche (2009); Hijazi I (Déroche 1983: 59 f., $\mathrm{n}^{\mathrm{o}}$ 2/3).

\section{B = Mingana Islamic Arabic 1572b}

7 folios; before 750?; Kufi B Ia.

The folios of the St. Petersburg collection Marcel 17 belong to this document as well. I have been unable to consult these.

\section{SM = Istanbul, Saray Medina 1a}

308 folios; late first/early second century; mixed.

T = Tübingen, Universitätsbibliothek, Ma VI 165

77 folios; ${ }^{14} \mathrm{C}$ : 649-675, o2 (95.4\%); Kufi B Ia.

\section{$\mathbf{M}=$ Cambridge, Cambridge University Library, Mingana-Lewis Palimpsest (small Quranic leaves)}

32 folios; later seventh/early eighth century; Hijazi.

This palimpsest, overwritten by Christian Arabic writing, was published at the beginning of the previous century by Alphonse Mingana and Agnes Smith Lewis (1914), and has recently been uploaded to the digital repository of the Cambridge University Library, wonderfully digitally retouched by Alba Fedeli. ${ }^{8}$

\section{The results}

Table 2 shows the spellings of ni mat as attested in the manuscripts examined. The sigla of the Quran manuscripts are given on the horizontal axis, where $\mathrm{C}$ stands for the Cairo edition, and vertically are the 15 locations of the spelling of ni mat. \& and $ت$ denote the spellings نعمد

7 Kufi C 1 is reported on Corpus Coranicarum. But the manuscript is evidently a Kufi B II manuscript.

8 https://cudl.lib.cam.ac.uk/view/MS-OR-01287-SMALL/1 
Table 2. The distribution of the two spellings of Ni mat allāah

\begin{tabular}{|c|c|c|c|c|c|c|c|c|c|c|c|c|c|c|c|}
\hline & $\mathrm{C}$ & Q & $\mathrm{BL}$ & $\mathrm{CP}$ & A3 & CA1 & $\mathrm{M}$ & $\mathrm{T}$ & SU & $\mathrm{SM}$ & $\mathrm{S}$ & W & $\mathrm{K}$ & B & Zid \\
\hline Q 2:211 & $d$ & & & & $d$ & & & & & & & $d$ & $d$ & & $d$ \\
\hline Q 2:231 & $ت$ & & & & $ت$ & & & & & & $ت$ & $ت$ & {$[\alpha]$} & & $ت$ \\
\hline Q 3:103 & $ت$ & $ت$ & & $ت$ & & & & & $ت$ & & & $ت$ & ت & & $ت$ \\
\hline Q 5:7 & $d$ & $d$ & & $d$ & & & & & $d$ & & & $d$ & $d$ & $d$ & $d$ \\
\hline Q 5:11 & $ت$ & $ت$ & $ت$ & $ت$ & & & & & & & & $ت$ & $ت$ & $ت$ & $ت$ \\
\hline Q 5:20 & $d$ & $d$ & $d$ & $d$ & & & & & & & & $d$ & $d$ & $d$ & $d$ \\
\hline Q 14:6 & d & & $\alpha$ & $d$ & & & & & & $d$ & & $d$ & $\alpha$ & & $d$ \\
\hline Q $14: 28$ & $ت$ & & $ت$ & $ت$ & $ت$ & $ت$ & & & & $ت$ & & $ت$ & $ت$ & & $ت$ \\
\hline Q $14: 34$ & $ت$ & & $ت$ & $ت$ & $ت$ & $ت$ & & & $ت$ & $ت$ & & $ت$ & $ت$ & & $ت$ \\
\hline Q $16: 18$ & $d$ & & $d$ & & $d$ & & $d$ & & & $\alpha$ & $d$ & $d$ & $d$ & & $d$ \\
\hline Q $16: 71$ & $d$ & & $d$ & & & & & & & $d$ & $d$ & $d$ & $d$ & & $d$ \\
\hline Q 16:72 & $ت$ & & ت & & & & & & & $ت$ & ت & $ت$ & $ت$ & & $ت$ \\
\hline Q 16:83 & $ت$ & & $ت$ & & & & $ت$ & & $ت$ & $ت$ & $ت$ & $ت$ & $ت$ & & $ت$ \\
\hline Q $16: 114$ & $ت$ & & ت & & $ت$ & & $ت$ & & $ت$ & $\alpha$ & ت & $ت$ & $ت$ & & $ت$ \\
\hline Q 29:67 & $d$ & & $d$ & & & & & $d$ & & $d$ & & & $d$ & & $d$ \\
\hline Q 31:31 & $ت$ & & $ت$ & & & & & $ت$ & $ت$ & $ت$ & & $ت$ & & & $ت$ \\
\hline Q 33:9 & $d$ & & $d$ & & & & & $d$ & $d$ & $\alpha$ & & $d$ & $d$ & & $d$ \\
\hline Q 35:3 & $ت$ & & $ت$ & & & & & $ت$ & $ت$ & $ت$ & & $ت$ & $ت$ & & {$\left[\begin{array}{l}ت \\
{[}\end{array}\right]$} \\
\hline Q 37:57 & $d$ & & $ت$ & & & & & & & $ت$ & $ت$ & $\alpha$ & $ت$ & & a \\
\hline Q 43:13 & $d$ & & $d$ & $d$ & & & & & & $d$ & & $d$ & $d$ & & $d$ \\
\hline Q 52:29 & $ت$ & & & & $ت$ & $ت$ & & & & & & $ت$ & $ت$ & & $ت$ \\
\hline Q 68:2 & $d$ & & & & & & & & & $d$ & & $d$ & $d$ & & $d$ \\
\hline Q 93:11 & $d$ & & & & & & & & & $d$ & & & $d$ & & \\
\hline
\end{tabular}


As can be seen in Table 2, there is an extremely strong correlation between the position of the idiosyncratic spellings in the Cairo edition and earlier Quranic manuscripts. With only two locations, Q 16:144 and Q 37:57, showing any disagreement at all. This great consistency cannot be attributable to chance.

For Q 16:114, only one manuscript disagrees with the general pattern, while the other seven manuscripts examined that have this form attested all employ the spelling found in the Cairo edition.

As for Q 37:57, two manuscripts have the same pattern as the Cairo edition, but the four others all have the spelling نعمت اله . It seems that here the Cairo edition is innovative along with $\mathrm{W}$ and $\mathrm{Zid}^{9}$

There is a further problem: $\mathrm{K}$ has a spelling for Q 2:231 that disagrees with the rest of the manuscripts. But this page is clearly written by a much later hand than other pages of this Codex, so this should not concern us. Zid has the same issue of a much later hand at Q 35:3, but in this case its spelling does agree with the other manuscripts.

\section{Implications}

There is only one possible explanation for the strong agreement across the many different Quran manuscripts with the two possible spellings of ni mat: there must have been a single written archetype from which all Quranic manuscripts of the Uthmanic text type are descended. Considering the early likely date of many of these manuscripts (second half of the seventh century), it is unlikely that the archetype of the "Uthmanic" text type postdates the canonical date assigned to it in the tradition - during 'Uthmān's reign (24-34 AH). Even an attribution of the Uthmanic text type to the so-called "second mașähif project"10 during the governorship of al-Hajjāj (75-95 AH) is difficult to accept. None of the narratives suggest such a radical change during this project, and several of the manuscripts examined here have upper date ranges in their carbon dating that precede al-Hajjāj's governorship by several decades. ${ }^{11}$ While it is of course impossible to prove that the standardization did not take place before 'Uthmān's reign on the basis of this data, the data is absolutely consistent with the traditional account.

A second implication of these results is that, from the very beginning of the text's standardization, every single manuscript that belongs to the Uthmanic text type must have been copied from a written exemplar. It is exactly these kinds of orthographic idiosyncrasies that would be impossible to reproduce through a process of writing down from dictation. And this general pattern of copying based on written exemplars from one manuscript to the next must have

9 Two other manuscripts available on Corpus Coranicum also have the spelling with a, namely Rampur Raza Library, No. 1 and Peterman I 38. Both of these are clearly considerably later than the manuscripts considered here, and it therefore seems that the spelling with $\alpha$ in Q 37:57 is an innovation typical to later manuscripts (and as such, shared with the Cairo edition). It should be noted that this is certainly not a regional variant. $\mathrm{W}$ is a Syrian mușhaf, while Zid is probably a Kufan mușhaf, judging from the variants listed by Cook (2004).

10 Hamdan 2010.

11 Namely, Ma VI 165 (53 AH) and Qāf 47 (30 AH). 
continued for centuries. While in this paper I have focused on the earliest possible Quranic manuscripts, these patterns clearly continue in later times, only markedly deviating from it, and using classicized spellings, in the Ottoman period. The Cairo edition is an intentional and quite successful return to form of the original rasm.

\section{Other orthographic idiosyncrasies}

We have examined the idiosyncratic distribution of the spelling of نعدث/نعمد الهه and have shown that this distribution is strongly correlated across many different Quranic manuscripts. This example gives more than enough evidence that there is an original written copy from which all other Quranic manuscripts stem, and that all Quranic manuscripts of the Uthmanic text type have been committed to writing not from memory, or copying from dictation, but copied from a previous written copy.

نعدى is not the only phrase whose spelling correlates strongly across many different Quranic manuscripts. All other phrases with the construct feminine that have either spelling likewise correlate consistently, e.g. رحمت/رحمه الله لعنه/لعنت اله etc.

There are other types of orthographic idiosyncrasies such as the spelling of jaz $\vec{a}^{\prime} u$ in construct, which is normally spelled جزاو 1 , but appears spelled as time and time again in five specific places: Q 5:29, 33, Q 42:40, Q 20:76 and Q 39:34. ${ }^{12}$ This specific distribution is likewise impossible to understand without the assumption of the copying of the Qurans from written exemplars.

Another point of orthographic variation is al-mala'u, spelled as الملا twelve times, but in four places in the Cairo edition is spelled الملو (Q 23:24, Q 27:29, Q 27:32, Q 27:38). Every single early Quranic manuscript that I have examined is in agreement that those are to be spelled as such, while the remaining are spelled in the regular way الملا.

It is important to note, however, that not all orthographic idiosyncrasies as encountered in the Cairo edition can be traced back to these early manuscripts, e.g. Q 40:50 du'à u l-kāfirinna دعوا الكفرين is spelled identically to Q 13:14 دعا in all the early Quranic manuscripts that I have examined. The spelling with دكفرين $w \bar{a} w$-'alif thus seems to be a later innovation.

Moreover, not all orthographic idiosyncrasies of the Uthmanic text type have been accurately transmitted up until the Cairo edition. For example, ابر هم/ابر هيخ for 'ibrāhìm is only spelled as ابر هم in Q 2 in the Cairo edition, while this spelling is much more haphazard but internally highly correlated in all early Quranic manuscripts. ${ }^{13}$

12 In these first three places, the Cairo edition spells the word and while this spelling is undoubtedly related, I have found no evidence for such a spelling in early Quranic manuscripts. Q 59:17 in the Cairo edition is also spelled جزوا, but I have found no evidence for such spellings in early manuscripts, and this therefore seems to be a later innovation.

13 This spelling is also strongly correlated to the reading of the Syrian transmitter Hišām 'an Ibn 'Āmir, who reads 'ibrāhām wherever it is spelled ابرهم in early manuscripts. Van Putten (forthcoming) discusses this in detail, and shows that Hišām's reading is based on the rasm, rather than the rasm being changed to suit Hišām's reading. 
The identification of such orthographic idiosyncrasies that are shared across these early Quranic manuscripts is an indispensable step in the study of the Quranic text, and essential for the creation of a critical edition of the Quranic rasm, and the reconstruction of the Uthmanic archetype. The identification of such idiosyncrasies and, perhaps, finding places where later manuscripts clearly deviate from earlier norms will allow us to reconstruct the trends and developments in the orthography of later Quranic manuscripts, and may even allow us to corroborate and/or further specify the stemmata of the early Quranic manuscripts identified by Cook (2004) in order to gain a better understanding of the spread and development of the Quranic text.

\section{The issue of scriptio plena of word-internal $\bar{a}$}

A final problem that comes into focus because of the examination of the highly consistent reproduction of orthographic idiosyncrasies in early Quranic manuscripts is the issue of the scriptio plena and scriptio defectiva of word-internal $\bar{a}$. As we have seen in this article, not only does the Uthmanic text type retain its word-order, verse order and surah order perfectly, it also consistently retains highly idiosyncratic spelling variations that must have existed in the Uthmanic archetype. Due to the strikingly consistent transmission of these idiosyncratic features, it is all the more surprising that when it comes to the plene or defective spelling of $\bar{a}$, there appears to be a fairly free variation of the two possibilities across Quranic manuscripts in certain environments.

This free variation captured the attention of Déroche (2009; 2014: $25 \mathrm{f}$.), who examined the internal spelling variations of several lexical items in the Codex Parisino-Petropolitanus and several other early Quranic manuscripts. He concludes that the inconsistent treatment across scribes suggests that the scribes of the Codex Parisino-Petropolitanus were upgrading the orthography towards a scriptio plena in comparison to the exemplar they were working from. It is unclear whether the exemplar from which the Codex Parisino-Petropolitanus was copied employed scriptio plena irregularly, and was subsequently accurately reproduced by the scribes, or whether the scribes were indeed upgrading the rasm, as Déroche suggests, towards having more scriptio plena. It should be noted that at least some degree of scriptio plena must have been part of the Uthmanic archetype.

For example, there is universal agreement that all stems with the shape $\mathrm{Ca} \mathrm{C}^{14}$ are spelled plene. ${ }^{15}$ No other stem shape displays such consistent spelling of the word-internal $\bar{a}$. This distribution is convincingly explained by Diem (1976: 258 f.; 1979: 251 f.). He points out that in the Nabataean Aramaic script ${ }^{16}$ - the predecessor of the Arabic script - there was no way of writing $\bar{a}$ word-internally. He therefore argues that the plene spelling of $\bar{a}$ is an innovation of the Hijazi (= Quranic) orthography. He suggests that this has happened due to the loss of the word-internal hamzah followed by compensatory lengthening. As a result,

$14 \mathrm{C}$ denotes any consonant, $\overline{\mathrm{C}}$ denotes a long consonant.

15 With the well-known exception, of course, of the verb qāla, which is generally spelled defectively (Déroche 2014: 47).

16 And in fact any type of Aramaic script. 
nouns with the original shape $\mathrm{Ca}^{\prime} \mathrm{C}$ would shift to $\mathrm{C} \overline{\mathrm{a}} \mathrm{C}$, and would thus end up having a similar shape to nouns that already had the historical shape $\mathrm{C} \overline{\mathrm{a}} \mathrm{C}$. As such, there were nouns with the shape $\mathrm{C} \overline{\mathrm{a}} \mathrm{C}$, some of which had a spelling with 'alif while others lacked it. The spelling with 'alif was subsequently generalized to all nouns of this shape, regardless of whether they originally contained a hamzah or not. This can be represented schematically as follows:

Stage 1.

Stage 2 .

Loss of

hamzah

*ra's >

راس

$*^{*} n \bar{a} r>$

ن

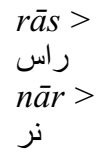

Stage 3.

Generalization of $\bar{a}$ spelling

rās

ر)

$n \bar{a} r$

نار

In stage 3 , the spelling of $n \bar{a} r$ with an 'alif should essentially be considered pseudo-historical. As there was no way to distinguish historical $\mathrm{Ca}$ ' $\mathrm{C}$ words from CāC nouns, simply every word with this shape was written with an 'alif.

Only after the generalization was complete (with the exception of the verb $q \bar{a} l a)$ did this new orthographic device of writing word-internal $\bar{a}$ spread to forms that could never have had a hamzah in that position, such as noun shapes like $\mathrm{CaC} \overline{\mathrm{a}} \mathrm{C}, \mathrm{Ca} \overline{\mathrm{C}} \overline{\mathrm{a}} \mathrm{C}$ and $\mathrm{C} \overline{\mathrm{C}} \mathrm{CiC}$. The orthography we find in the early Quranic manuscripts as well as in the Cairo edition of the Quran seems to be in a transitional period towards the plene writing of such nouns, where it seems to be essentially optional whether $\bar{a}$ is written plene or not. When we compare such spellings across early Quranic manuscripts, e.g. one of the nouns that Déroche studied for the Codex Parisino-Petropolitanus, 'ibād, we find that even manuscripts that are all part of the Syrian manuscript type (i.e. Codex ParisinoPetropolitanus, Or. 2165 and We II 1913) there appears to be free variation across the manuscripts, and the positions where they show up do not seem to correlate at all.

Table 3 tabulates all occurrences of 'ibād across all three manuscripts. ${ }^{17}$ As can be seen there is no clear agreement or trend between these three manuscripts, showing that the presence or absence of the 'alif does not seem to be unique to Syrian manuscripts. This trend remains the same when we include codices of the Kufan, Basran, or Medinan type.

So while there are many examples of orthographic idiosyncrasies which were faithfully reproduced for hundreds of years in Quranic codices, it appears that the scribal tradition that produced these copies placed no value on the accurate

17 While the other word examined by Déroche, 'adhāb, might also be examined, it is more difficult to judge the examples because the 'alif in عذاب is unconnected on both sides. As such, a later hand could have easily added an 'alif to the word. This is also quite obviously something that has happened in We II 1913, but there is too high a chance that

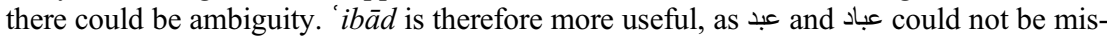
taken for each other, even if a later hand adds an 'alif. 
Table 3. The spelling of 'ibād

\begin{tabular}{|c|c|c|c|}
\hline & $\mathrm{CP}$ & BL & W \\
\hline Q 7:128 & عبده & عبده & عباده \\
\hline Q 7:194 & عبد & عبد & عباد \\
\hline Q 10:107 & عبده & عبذه & عباده \\
\hline Q $14: 11$ & عبده & عبده & عباده \\
\hline Q $14: 31$ & لعبدى & لعبدى & لعبادى \\
\hline Q $15: 40$ & عبادك & عبادك & عبادك \\
\hline Q 15:42 & عبادى & عبدى & عبادى \\
\hline Q 15:49 & عبدى & عبدى & عبادى \\
\hline Q 23:109 & عبدى & عبدى & عبادى \\
\hline Q $24: 32$ & عبد & عبد & عباد \\
\hline Q $25: 17$ & عبدى & عبدى & عبادى \\
\hline Q 25:58 & عبده & عباده & عباده \\
\hline Q $25: 63$ & عبد & عبد & عباد \\
\hline Q 26:52 & يعبدى & بعبدى & يعبادى \\
\hline Q $27: 15$ & عبده & عبده & عباده \\
\hline Q 27:19 & عبدك & عبدك & عبادك \\
\hline Q 27:59 & عبده & عبده & عباده \\
\hline Q $35: 28$ & عباده & عباده & عباده \\
\hline Q 35:31 & بعبده & بعباده & بعباده \\
\hline Q 35:32 & عبدنا & عبدنا & عُبادنا \\
\hline Q 38:83 & عبادك & عبدك & عبدك \\
\hline Q 39:7 & لعبده & لعبده & لعباده \\
\hline Q 39:10 & بعبد & بعبد & بعباد \\
\hline Q 42:19 & بعبده & بعبده & بعباده \\
\hline Q $42: 23$ & عباده & عباده & عباده \\
\hline Q 42:25 & عباده & عباده & عباده \\
\hline Q $42: 27$ & لعبده & لعباده & لعباده \\
\hline Q 43:15 & عباده & عباده & عباده \\
\hline Q 43:1918 & عبد & عبد & عبد \\
\hline Q 43:68 & يعبدى & يعبدى & يعبدى \\
\hline
\end{tabular}

reproduction of the specific orthographic idiosyncrasy of writing a word $\bar{a}$ with an 'alif or not. ${ }^{19}$

Even if we assume that Déroche is correct and that scribes were essentially "upgrading" the orthography of the exemplar from which they were copying, we cannot assume that, whenever early manuscripts are in disagreement with each other, the spelling without the 'alif is the older one. There seems to be a more general "carelessness" when it comes to word-internal 'alifs also when

18 As Ibn 'Āmir (and Ibn Kāthīr and Nāfi') reads this word as 'inda, its being written defectively in these three Syrian muṣhafs should not surprise us (Ibn Mujāhid n.d., 585).

19 It is interesting to note that the so-called "Second Mașāhif project" of al-Hajjāj in some accounts seems to point to the addition of 'alifs (Hamdan 2010: $796 \mathrm{ff}$.). While these accounts can be problematized, it is nevertheless striking that it is precisely in the case of the 'alif that no clear adherence to the copying of orthographic idiosyncrasies from a single written archetype can be observed. This might indicate that such a process did in fact take place. 
they do not denote $\bar{a}$. For example, مايه mi ah "hundred" and شاى shay' "thing"

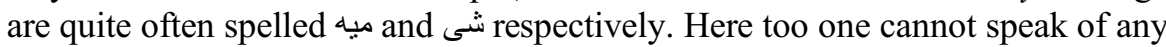
faithful reproduction of the orthographic idiosyncrasies across multiple early Quranic manuscripts. Table 4 examines the spelling of مايه "hundred" (and مايتين "two hundred") across the early Quranic manuscripts examined above. Here it is clear that no consistent pattern emerges between the orthography of different Quran manuscripts.

In other words, word-internal 'alifs that do not obviously denote $\bar{a}$ are not controlled for in the scribal tradition that produced these early Quranic manuscripts. However, scholars are in general agreement that the spelling with the 'alif in mi'ah and shay' is the more archaic spelling, while the one without is innovative (e.g. Diem 1980: 103 f.). So the addition and the removal of word-internal 'alifs appears to have been dependent on the scribe's own discretion. It does not therefore seem productive, when discussing Quranic orthography, to think in absolute terms of archaic and innovative spellings of the 'alif; clearly, at the time of the earliest Quranic manuscripts available to us both the archaic and innovative spellings were co-existent. There is no reason to assume that this situation was any different at the time of the writing of the Uthmanic archetype several decades earlier. Nor is there a reason to believe that when one spelling or the other is attested, the Uthmanic archetype must have had the more archaic form. Until further evidence appears, or a better understanding of the vacillation of the word-internal 'alif is reached, it is certainly premature to speak of an upgrading of the orthography from a scriptio defectiva towards a scriptio plena.

While this issue of plene and defective writing presents a problem for the reconstruction of the rasm of the Uthmanic archetype it should be stressed that this issue affects only a minority of words that contain a word-internal $\bar{a}$. A majority of words with word-internal $\bar{a}$ have a predictable spelling across all early Quranic manuscripts as well as in the Cairo edition. Some of these orthographic principles were set out by Diem (1979: $255 \mathrm{f}$.), and I summarize them here. In some places I have provided additions to Diem's generalizations. As Diem based his generalizations exclusively on the Cairo edition, manuscript evidence occasionally disagrees with these generalizations.

1. $\mathrm{C} \overline{\mathrm{a}} \mathrm{C}$ and $\mathrm{C} \overline{\mathrm{a}} \overline{\mathrm{C}}$ are invariably written plene (with the exception of $q \bar{a} l a$ ).

2. Active participles in the sound plural masculine, feminine or dual are always

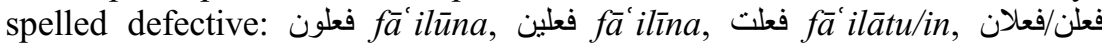
fāi ilāni, فعلين fāilayni. ${ }^{20}$

3. The feminine plural ending $-\bar{a} t$ is spelled defectively, but if this means the word consists of only three letters, it is spelled plene, e.g. مسلمت muslimāt but بنات banāt, جنات jannāt, ${ }^{21}$ sayyi àt.

4. The nominal ending $-\bar{a} n$ is spelled defectively, e.g. رحمن rahmān.

20 This includes medial weak active participles, a type of active participle which the Cairo edition invariably writes plene both in the singular and plural. This regularity is absent in early Quranic manuscripts, and must be seen as an orthographic innovation in the Cairo edition.

21 This is normally spelled defectively in the Cairo edition (with the exception of Q 42:22), but this seems to be an idiosyncrasy of the Cairo edition. 
Table 4. The spelling of mi'ah

\begin{tabular}{|c|c|c|c|c|c|c|c|c|c|c|c|c|}
\hline & $\mathrm{C}$ & $\mathrm{BL}$ & $\mathrm{CP}$ & A3 & CA1 & $\mathrm{T}$ & SU & SM & $\mathrm{S}$ & W & $\mathrm{K}$ & Zid \\
\hline Q 2:259 & ـاي & & & & & & ـاي & & Lاي & هاي & ايـ & ايب \\
\hline Q 2:259 & ايب & & & & & & ايـ & & Lاي & ـاي- & ـاي- & ـايـ \\
\hline Q 2:261 & ايب & & & & & & Lاي & & Lاي & ـاي- & ايب & ـايـ \\
\hline Q 8:65 & ايـ & Lاي & Lاي & هاي & Lاي & & Lاي & $\div$ & & ـاي- & $\div$ & ـايـ \\
\hline Q 8:65 & ايـ & ايـ & $\div$ & ايـ & ايـ & & ايـ & $\div$ & & Lاي & ايه & ـايـ \\
\hline Q 8:66 & ايب & Lاي & $\div$ & ايـ & Lاي & & Lاي & $\div$ & & ـاي- & لـاي & ـايـ \\
\hline Q 8:66 & ايـ & ايـ & Lايـ & ايـ & ايب & & ايـ & $\div$ & & ايب & $\div$ & -ايـ \\
\hline Q 18:25 & ايـ & ايب & & & & Lايـ & & $\div$ & & ايب & ايـ & -ايـ \\
\hline Q 24:2 & ايـ & ايـ & $\div$ & & & لايب & & ايـ & & Lايـ & ايـ & -ايـ \\
\hline Q 37:147 & ايب & Lاي & & & & & 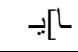 & $\div$ & Lاي & $\div$ & لايب & - ايـ \\
\hline
\end{tabular}


Table 5. The spelling of $y \bar{a} b i s \bar{a} t$

\begin{tabular}{ccccccccc}
\hline & C & BL & L $^{22}$ & SU & SM & W & K & Zid \\
\hline Q 12:43 & L & $L$ & & $L$ & $L$ & $L$ & $L$ & $L$ \\
Q 12:46 & $L$ & $L$ & $L$ & $L$ & $L$ & $L$ & $L$ & $L$ \\
\hline
\end{tabular}

5. The proclitic vocative particle $y \bar{a}$ - is always defective.

6. The proclitic demonstrative $h \bar{a}$ - is always defective.

7. The 1pl. pf. ending $-n \bar{a}$ word-internally is always defective.

8. Words that are spelled defectively in Classical Arabic are also spelled defectively in the Quran, e.g. لكن lākin(na), اوليك ذلك dhälika, etc.

9. Many words are simply always spelled defectively, e.g. صرط șirāt; المليكه al-malä ikah; thalāth; Many names are always spelled

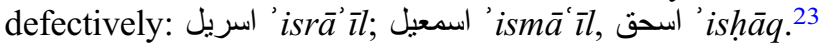

Whenever exceptions to the rules formulated above appear, these seem to form consistent orthographic idiosyncrasies which can therefore be reconstructed for the Uthmanic archetype despite involving a word-internal 'alif. One such an example is يابست yābisātin in Q 12:43 and Q 12:46. If we examine the spelling of this word in old Quranic manuscripts, we find the exact same pattern. The general orthographic rule clearly predicts a defective spelling, but it is not found for this one word in any early Quranic manuscript, as can be seen in Table 5. Therefore, one should conclude that the Uthmanic archetype certainly had يابست, as there is no way of accounting for such an idiosyncratic spelling otherwise.

As such, we should also conclude that for this word, a plene spelling was present in the Uthmanic archetype, and that we cannot simply assume that the Uthmanic archetype was spelled completely defectively.

This clearly shows why spellings should not be subjected to an ad hoc per manuscript study, but rather should be placed within a systematic comparative study. Only once we have established the general orthographic principles we can start making reasonable inferences about which 'alif may be a later addition and which may not, and why.

\section{Conclusion}

This paper has shown that idiosyncratic spellings of certain words are not due to the whims of the scribe, but are reproduced with the same spelling in all early Quranic manuscripts. The only way that such a consistent reproduction can be explained is by assuming that all the documents that belong to the Uthmanic text type go back to a single written archetype whose spelling was strictly copied from one copy to the next, showing that these copies were based on a written exemplar.

22 Leiden, Universiteitsbibliotheek, Or. 6814, ${ }^{14} \mathrm{C}: 680-798$, 62 (95.4\%) (Coranica); Kufic.

23 This final category of defective spellings hardly forms a systematic category of course. The generalization nevertheless remains robust. A systematic study and, hopefully, further specification of conditioning, may help us better formulate reasonable reconstructible principles for the Uthmanic archetype. 
The manuscripts examined in this study are sufficiently early that a codification of the Uthmanic text type is perfectly consistent with an attribution to its traditional source: 'Uthmān b. 'Affān.

Moreover, this article has discussed the perplexing case of the alternation between scriptio plena and scriptio defectiva. There seems to be no clearly accurate transmission when it comes to the writing of the medial 'alif for $\bar{a}$. Nevertheless, the patterns and generalizable rules make it clear that the Uthmanic archetype was not written completely scriptio defectiva. Certain words would have surely been written plene while others would have been written defectively, even in the Uthmanic archetype. Close examination of the patterns across different Quranic manuscripts may give us a better sense of the patterns and development of the plene spelling of $\bar{a}$ in early Quranic manuscripts.

\section{Bibliography}

Burton, John. 1977. The Collection of the Qur'ān. Cambridge: Cambridge University Press.

Cellard, Éléonore. 2017. Codex Amrensis 1. Leiden and Boston: Brill.

Cook, Michael. 2004. "The stemma of the regional codices of the Koran", in G.K. Lividas (ed.), Graeco-Arabica 9-10: Festschrift in Honour of V. Christides. Athens: Institute for Graeco-Oriental and African Studies, 89-104.

Corpus Coranicum = Manuscripta Coranica . Berlin: Berlin-Brandenburg Academy of Sciences and Humanities. Database accessible online at www.corpuscoranicum.de.

Déroche, François. 1983. Les manuscrits du coran: Aux origines de la calligraphie coranique. Paris: Bibliothèque nationale.

Déroche, François. 1992. The Abbasid Tradition: Qur'ans of the 8th to the 10th centuries $A D$. Oxford: Oxford University Press.

Déroche, François. 2009. La transmission écrite du Coran dans les débuts de l'islam: Le codex Parisino-petropolitanus. Leiden and Boston: Brill.

Déroche, François. 2014. Qur'ans of the Umayyads: A First Overview. Leiden and Boston: Brill.

Diem, Werner. 1976. "Some glimpses at the rise and early development of the Arabic orthography", Orientalia 45, 251-61.

Diem, Werner. 1979. "Untersuchungen zur frühen Geschichte der arabischen Orthographie. I: Die Schreibung der Vokale", Orientalia 48, 207-57.

Diem, Werner. 1980. "Untersuchungen zur frühen Geschichte der arabische Orthographie II: Die Schreibung der Konsonanten", Orientalia 49, 67-106.

Donner, Fred M. 2008. "The Qur' ān in recent scholarship: challenges and desiderata”, in G.S. Reynolds (ed.), The Qur'ān in Its Historical Context. London and New York: Routledge.

Dutton, Yasin. 2001. "An early Muṣhaf according to the reading of Ibn 'Āmir”, Journal of Quranic Studies 3/1, 71-89.

Dutton, Yasin. 2004. "Some notes on the British Library's 'oldest Qur'an manuscript' (Or. 2165)", Journal of Quranic Studies 6/1, 43-71.

Hamdan, Omar. 2010. "The second Mașăhif project: a step towards the canonization of the Qur' anic text", in A. Neuwirth, N. Sinai and M. Marx (eds), The Qur'an in Context: Historical and Literary Investigations into the Qur'ānic Milieu. Leiden and Boston: Brill, 795-835. 
Hamdūn, R.Ġ. 2004. Al-Makhtūtât al-Qur' āniyyah fì San 'à mundhu al-Qarn al-'Awwal al-Hijrī wa Hifz al-Qur'ān al-Karīm bi-l-Sutūur. Unpublished MA dissertation, Al-Yemenia University, Sanaa.

Hilali, Asma. 2017. The Sanaa Palimpsest: The Transmission of the Qur'an in the First Centuries AH. Oxford: Oxford University Press.

Ibn Mujāhid. n.d. Kitāb al-Sab'ah fì al-Qirā'àt. Cairo: Dār al-Ma ārif.

Motzki, Harald. 2001. "The collection of the Qur'ān: a reconsideration of Western views in light of recent methodological developments", Der Islam 78, 1-34.

Nasser, Shady Hekmat. 2013. The Transmission of the Variant Readings of the Qur' ann: The Problem of Tawātur and the Emergence of Shawādhdh. Leiden and Boston: Brill.

Neuwirth, Angelika. 2003. "Qur'an and history - a disputed relationship. Some reflections on Qur' anic history and history in the Qur'an", Journal of Qur'anic Studies 5/1, $1-18$.

Putten, Marijn van. Forthcoming. "Hishām's 'Ibrāhām. Evidence for a canonical Quranic reading based on the rasm", Journal of the Royal Asiatic Society.

Sadeghi, Behnam and Uwe Bergmann. 2010. "The codex of a Companion of the Prophet and the Qur' ān of the Prophet", Arabica 57, 343-436.

Sadeghi, Behnam and Mohsen Goudarzi. 2012. "Șan ' $\bar{a}$ ' 1 and the origins of the Qur'ān", Der Islam 87, 1-129.

Sinai, Nicolai. 2014a. "When did the consonantal skeleton of the Quran reach closure? Part I", BSOAS 77/2, 273-92.

Sinai, Nicolai. 2014b. "When did the consonantal skeleton of the Quran reach closure? Part II", BSOAS 77/3. 509-21.

Wansbrough, John. 1977. Quranic Studies: Sources and Methods of Scriptural Interpretation. Amherst, NY: Prometheus Books. 